\title{
Are Au Nanoparticles on Oxygen-Free Supports Catalytically Active?
}

\author{
Alexander Yu. Klyushin ${ }^{1} \cdot$ Rosa Arrigo $^{1} \cdot$ Yi Youngmi ${ }^{1} \cdot$ Zailai Xie $^{1}$ • \\ Michael Hävecker ${ }^{1,2} \cdot$ Andrey V. Bukhtiyarov ${ }^{3,4}$ - Igor P. Prosvirin ${ }^{3,4}$. \\ Valerii I. Bukhtiyarov ${ }^{3,4} \cdot$ Axel Knop-Gericke ${ }^{1} \cdot$ Robert Schlögl $^{1}$
}

Published online: 11 January 2016

(c) The Author(s) 2016. This article is published with open access at Springerlink.com

\begin{abstract}
Gold nanoparticles (Au NPs) on oxygen-free supports were examined using near ambient pressure X-ray photoelectron spectroscopy under $\mathrm{CO}$ oxidation conditions, and ex situ using scanning electron microscopy and transmission electron microscopy. Our observations demonstrate that Au NPs supported on carbon materials are inactive, regardless of the preparation method. Ozone $\left(\mathrm{O}_{3}\right)$ treatment of carbon supports leads oxygen-functionalization of the supports. When subsequently exposed to a $\mathrm{CO}$ feed, $\mathrm{CO}$ is oxidized by the functionalized sites of the carbon support via a stoichiometric pathway. Microscopy reveals that the reaction with $\mathrm{CO}$ does not change the morphology of the Au NPs. In situ XPS reveals that the $\mathrm{O}_{3}$ treatment gives rise to additional $\mathrm{Au} 4 \mathrm{f}$ and $\mathrm{O} 1 \mathrm{~s}$ peaks at binding energies of $85.25-85.6$ and $529.4-530 \mathrm{eV}$, respectively, which are assigned to the presence of $\mathrm{Au}$ oxide. A surface oxide phase is formed during the activation of $\mathrm{Au}$ NPs supported on $\mathrm{Au}$ foil by $\mathrm{O}_{3}$ treatment. However, this phase decomposes in vacuum and the
\end{abstract}

Electronic supplementary material The online version of this article (doi:10.1007/s11244-015-0528-0) contains supplementary material, which is available to authorized users.

Alexander Yu. Klyushin

klyushin@fhi-berlin.mpg.de

1 Fritz-Haber-Institute der Max Planck Society, Faradayweg 4-6, 14195 Berlin, Germany

2 Division Solar Energy Research, Helmholtz-Zentrum Berlin für Materialien und Energie GmbH, Albert-Einstein-Str. 15, 12489 Berlin, Germany

3 Boreskov Institute of Catalysis, Pr. Lavrentieva 5, Novosibirsk 630090, Russia

4 Novosibirsk State University, Piragova str. 2, Novosibirsk 630090, Russia remaining low-coordinative atoms do not have sufficient catalytic properties to oxidize $\mathrm{CO}$, so the size reduction of $\mathrm{Au}$ NPs and/or oxidation of Au NPs is not sufficient to activate $\mathrm{Au}$.

Keywords Gold nanoparticles · Gold oxide $\cdot$ X-ray photoemission spectra $\cdot$ Surface core-level shift $\cdot$ CO oxidation $\cdot$ Strong metal-support interaction

\section{Introduction}

Gold-based catalysts have attracted a lot of interest since Haruta's study [1, 2]. Au catalytic systems demonstrate high activity in many application, in particular in complete $[3,4]$, selective $[5,6]$ and partial $[3,7]$ oxidation reactions. The number of publications on the application of $\mathrm{Au}$ in catalysis increases each year; however, the mechanism of the reactions is still debated in the literature.

The complexity of Au-containing catalysts suggests many possible factors may influence the catalytic activity of gold, such as particle size and shape, the support morphology and nature, activation (pre-)treatment, presence of adsorbed oxygen or water etc. In the literature, there is no consensus about active species; some authors consider metallic gold $[8,9]$ as active sites, while others suggest positive $(\delta+)[10,11]$ and negative $(\delta-)[12,13]$ lowcharged gold or oxidized $(1+, 3+)$ states [14]. Identification of active sites requires a systematic study of Au-based catalysts, by varying one or few parameters. One of the potentially most important parameters is the support. Therefore we divide Au catalytic systems into two broad groups: Au on oxygen-free supports and $\mathrm{Au}$ on oxides.

Here, we present a study of Au catalysts on oxygen-free supports in the $\mathrm{CO}$ oxidation reaction, using a combination 
of in situ XPS and ex situ transmission electron microscopy (TEM) and scanning electron microscopy (SEM). Near ambient pressure X-ray photoelectron spectroscopy (NAPXPS) measurements allow us to characterize the electronic structure of nanoscopic Au and support, while microscopy provides information about morphology of Au NPs before and after reaction. The combination of these techniques helps one to understand the origin of Au catalytic activity and clarify the mechanism of the reaction.

\section{Materials}

\section{$2.1 \mathrm{Au} / \mathrm{HOPG}$}

Model Au/HOPG catalysts were prepared inside a preparation chamber attached to a photoelectron spectrometer (Novosibirsk, Russia) which was built by SPECS (Germany). The analyzer chamber was equipped with a hemispherical analyzer PHOIBOS-150-MCD-9, an ellipsoidal monochromator FOCUS 500 and an X-ray source XR $50 \mathrm{M}$ with double Al/Ag anode. The three-step preparation procedure, previously used to prepare Ag/HOPG (highly oriented pyrolytic graphite) model catalysts, as described in detail elsewhere [15], was used to prepare Au/HOPG model catalysts. This procedure consists of an initial stage of defect formation on the HOPG surface by soft $\mathrm{Ar}^{+}$ sputtering followed by Au deposition and surface annealing at $\mathrm{T}=300{ }^{\circ} \mathrm{C}$ in UHV (for Au NPs stabilization). The Au nanoparticle size was varied by changing the amount of deposited gold, which was controlled by monitoring the ratio of $\mathrm{Au} 4 \mathrm{f}$ to $\mathrm{C} 1 \mathrm{~s}$ XPS peak areas, a final Au load was 1 $\mathrm{wt} \%$.

\section{$2.2 \mathrm{Au} / \mathrm{N}-\mathrm{CNTs}$}

Multi-walled carbon nanotubes were supplied by Applied Science ltd. $20 \mathrm{~g}$ CNTs were treated with $1 \mathrm{~L}$ of concentrated $\mathrm{HNO}_{3}$ under reflux for $4 \mathrm{~h}$. Then the nanotubes were filtrated and washed with distilled water until the filtrate showed a neutral $\mathrm{pH}$. Subsequently, the sample was dried at $110{ }^{\circ} \mathrm{C}$ for $3 \mathrm{~d}$ in air. N-functionalized CNTs (N-CNTs) were obtained via a treatment of the previously oxidized nanotubes with $\mathrm{NH}_{3}$ at $700{ }^{\circ} \mathrm{C}$ for $6 \mathrm{~h}$. For this purpose $3 \mathrm{~g}$ of the material were placed in a quartz tube under a flow of $120 \mathrm{~mL} / \mathrm{min}$ composed of $10 \% \mathrm{NH}_{3}$ in $\mathrm{Ar}$.

$5 \mathrm{mg}$ of $\mathrm{NaN}_{3}$ were dissolved in $10 \mathrm{~mL}$ of MilliQ water. Then $6 \mathrm{mg}$ of trihydrate chloroauric acid $\left(\mathrm{HAuCl}_{4} \cdot 3 \mathrm{H}_{2} \mathrm{O}\right)$ were added to the solution, which subsequently turned orange. The ratio $\mathrm{NaN}_{3} / \mathrm{HAuCl}_{4} \cdot 3 \mathrm{H}_{2} \mathrm{O}$ was $5: 1.300 \mathrm{mg}$ of $\mathrm{N}-\mathrm{CNT}$ s were added to the solution in order to allow the adsorption of the Au precursor on the N-CNTs with a final $\mathrm{Au}$ load of $1 \mathrm{wt} \%$. The addition of the N-CNTs induced gas release and caused the solution to turn colorless, indicating the decomposition and complete adsorption of the precursor. Afterwards, the N-CNT suspension was filtered and the total precursor decomposition was ensured by phototreatment with an UV/Vis lamp for $30 \mathrm{~min}$.

\section{$2.3 \mathrm{Au} / \mathrm{O}-\mathrm{CNTs}$}

$10 \mathrm{~g}$ Baytubes C150HP were treated with $500 \mathrm{~mL}$ of 3 molar $\mathrm{HNO}_{3}$ [diluted with water from nitric acid $65 \%$ (Merck)] at room temperature (RT) for $24 \mathrm{~h}$. Then the O-functionalized CNTs (O-CNTs) were thoroughly washed and filtrated with Millipore water until a neutral $\mathrm{pH}$ was obtained. For the synthesis of Au/O-CNT, $1 \mathrm{~g}$ of O-CNTs was impregnated with $6 \mathrm{~mL}$ aqueous solution containing $20.2 \mathrm{mg}$ of $\mathrm{HAuCl}_{4}$. The slurry was then sonicated in an ultrasonic bath for $10 \mathrm{~s}$ and afterwards the solvent was evaporated slowly at RT in air for $48 \mathrm{~h}$. Thereafter, the samples containing the metal precursor were reduced in $20 \% \mathrm{H}_{2} / \mathrm{Ar}$ gas mixture at $250{ }^{\circ} \mathrm{C}$ for $2 \mathrm{~h}$, a final $\mathrm{Au}$ load was $1 \mathrm{wt} \%$.

\subsection{Au/Au Foil}

$\mathrm{Au}$ nanoparticles on $\mathrm{Au}$ foil were prepared by electrodeposition. Electrochemical deposition was performed in a conventional three-electrode electrochemical cell using a potentiostat/galvanostat (VSP, Biologic). Au foil was used as the working electrode and Pt wire and saturated calomel electrode (SCE) were employed as the counter electrode and the reference electrode. Au electrolyte solution consisted of $0.1 \mathrm{mM} \mathrm{HAuCl}_{4}+0.1 \mathrm{M} \mathrm{HCl}$. Au nanoparticles were then electrodeposited under a current potential of $-0.4 \mathrm{~V}$ versus SCE for $60 \mathrm{~s}$.

\section{Methods}

\subsection{XPS}

The NAP-XPS experiments were performed at the ISISS beamline of BESSY II/HZB (Berlin, Germany). All measurements were carried out in a stainless steel NAP-XPS chamber, the details of which are described elsewhere [16, 17]. The powder samples were pressed into a pellet of $8 \mathrm{~mm}$ diameter. Samples were placed between a stainless steel backplate and lid (with $6 \mathrm{~mm}$ hole) and mounted onto a sapphire sample holder. The samples were heated from the backside using an infrared laser and the temperature 

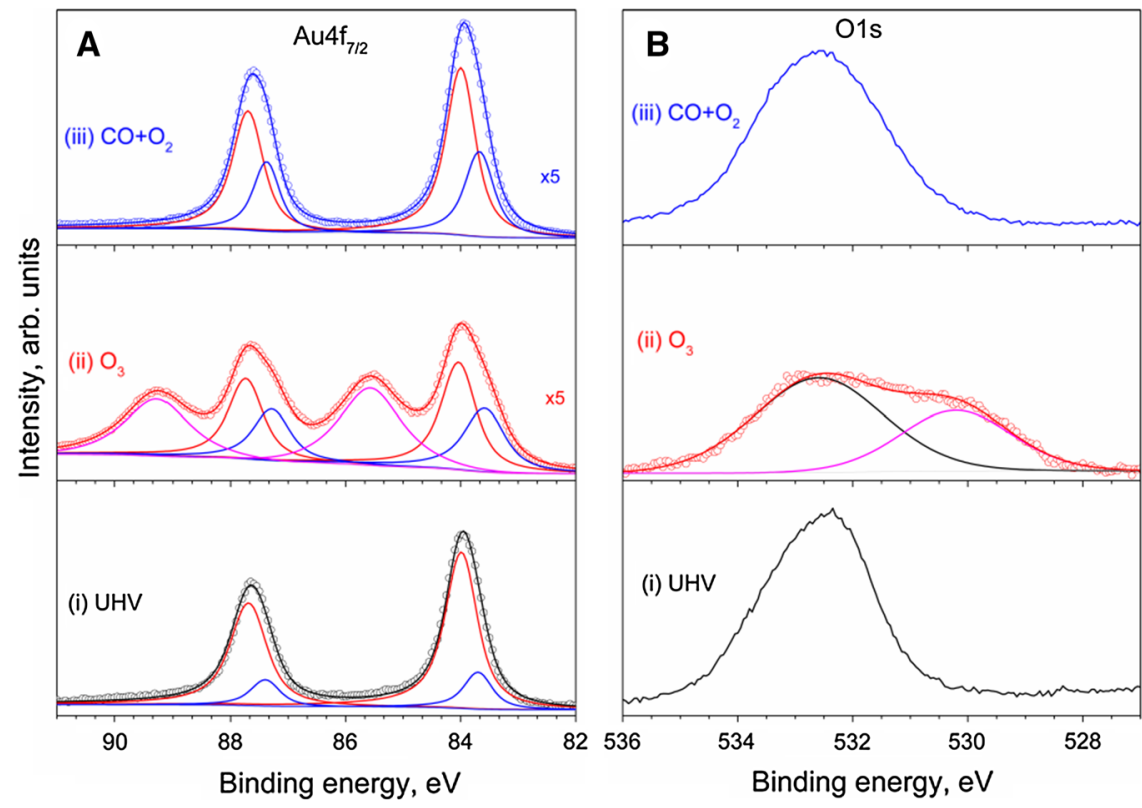

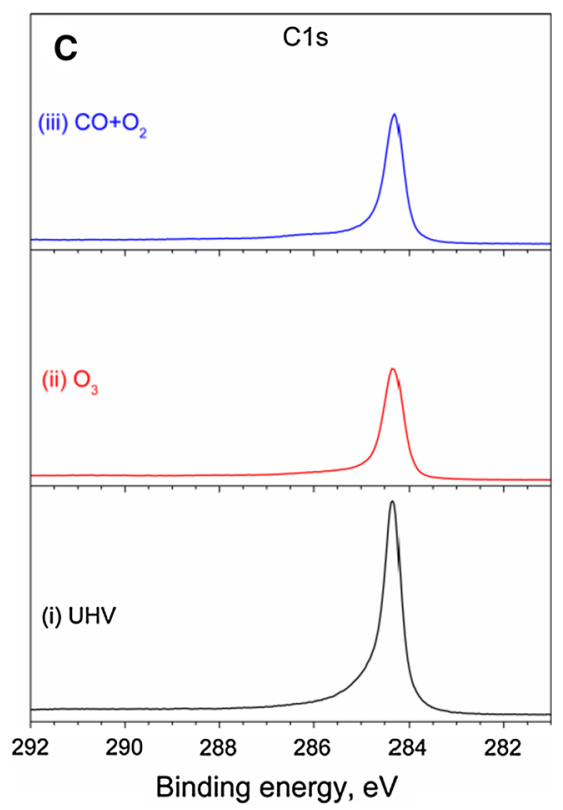

Fig. 1 NAP a Au 4f, b O 1s and c C 1s XP spectra of Au/HOPG $(i)$ in UHV at RT, (ii) under $\mathrm{O}_{3}$ at $p=0.3 \mathrm{mbar}, \mathrm{T}=100{ }^{\circ} \mathrm{C}$ and (iii) under $\mathrm{CO}$ and $\mathrm{O}_{2}$ atmosphere at $p=0.3 \mathrm{mbar}$, RT. Photoelectrons with $150 \mathrm{eV}$ kinetic energy were used to collect surface sensitive $\mathrm{Au}$ 4f, $\mathrm{O}$ 1s and $\mathrm{C}$ 1s spectra in UHV and $\mathrm{CO}+\mathrm{O}_{2}$, and photons with $720 \mathrm{eV}$ energy were used to collect $\mathrm{Au} 4 \mathrm{f}, \mathrm{O} 1 \mathrm{~s}$ and $\mathrm{C} 1 \mathrm{~s}$ spectra during $\mathrm{O}_{3}$ treatment

\section{Results}

surface. The overall spectral resolution was $0.3 \mathrm{eV}$ in $\mathrm{O} 1 \mathrm{~s}$ and $0.2 \mathrm{eV}$ in $\mathrm{Au} 4 \mathrm{f}$ regions. The spectra intensity was normalized to the incident photon flux, which was measured using a Au foil. The core level binding energies (BE) were calibrated using the Fermi edge, $\mathrm{C} 1 \mathrm{~s}$ and $\mathrm{Au} 4 \mathrm{f}_{7 / 2}$ second order peak. The accuracy of BE calibration was estimated to be around $0.05 \mathrm{eV}$.

All XP spectra were collected in normal photoemission mode. For quantitative XPS analysis, least-squares fitting of the spectra were performed using CasaXPS software (www.casaxps.com). A Doniach-Sunjic line shape for $\mathrm{Au}$ $4 \mathrm{f}_{7 / 2}$ and a product (multiplication) of a Gaussian with a Lorentzian line shape for $O$ 1s with Shirley-type background were used to obtain the best fit. For surface composition calculation the cross section tables of Yeh and Lindau were used [18] and the correction for the different electron inelastic mean free pass was done using QUASESIMFP-TPP2 M software (http://www.quases.com/products/ quases-imfp-tpp2m/).

$\mathrm{O}_{3}$ was produced using a commercial ozone generator TC$1 \mathrm{KC}$. Oxygen was flowed through Teflon tubing to the ozone generator at a rate of $1 \mathrm{~L} / \mathrm{min}$. The effluent gas of the generator contained a mixture of approximately $1 \%$ ozone and $99 \%$ un-reacted oxygen. The $\mathrm{O}_{3} / \mathrm{O}_{2}$ mix was dosed into the experimental cell using a leak valve. $\mathrm{O}_{2}$ and $\mathrm{CO}$ were dosed into the experimental cell in different ratios using mass-flow controllers (MFC) at a sample temperature of $100{ }^{\circ} \mathrm{C}$. The total pressure in the experimental cell was 0.3 mbar.

\subsection{Au/HOPG}

The first step to study the Au catalyst is to characterize the freshly prepared samples. Photoelectrons with $150 \mathrm{eV}$ kinetic energy were used to collect surface sensitive $\mathrm{Au} 4 \mathrm{f}$, $\mathrm{O}$ 1s and $\mathrm{C}$ 1s spectra in $\mathrm{UHV}$ and $\mathrm{CO}+\mathrm{O}_{2}$, and photons with $720 \mathrm{eV}$ energy were used to collect $\mathrm{Au} 4 \mathrm{f}, \mathrm{O}$ 1s and $\mathrm{C}$ 1s spectra during $\mathrm{O}_{3}$ treatment (Fig. 1). Au $4 \mathrm{f}$ spectrum of the fresh Au/HOPG in UHV at RT [Fig. 1a(i)] shows one sharp peak at a binding energy (BE) of $83.95 \mathrm{eV}$, assigned to bulk $\mathrm{Au}$ in the metallic state, according to the literature [19-21]. The component shifted to low BE by the $0.3 \mathrm{eV}$ is usually assigned to low-coordinated Au atoms [22]. The corresponding $\mathrm{O}$ 1s spectrum shows the presence of oxygen on the surface [Fig. 1b(i)]. The asymmetry of $\mathrm{O} 1 \mathrm{~s}$ peak indicates that there is more than just one oxygen specie and the position of its maximum (BE $532.6 \mathrm{eV}$ ) suggests the presence of $\mathrm{C}-\mathrm{O}, \mathrm{C}=\mathrm{O}$ and/or $\mathrm{C}-\mathrm{OH}$ bonds [23, 24]. C 1s spectrum [Fig. 1c(i)] shows well-known graphite peak at $\mathrm{BE}$ of $284.3 \mathrm{eV}$ [25].

When the $\mathrm{O}_{2} / \mathrm{O}_{3}$ mixture was introduced into the chamber and the sample was heated to $100{ }^{\circ} \mathrm{C}$, the $\mathrm{Au} 4 \mathrm{f}$ spectrum changed [Fig. 1a(ii)]. A well-defined peak appears at $85.6 \mathrm{eV}$, which is assigned to an ionic $\mathrm{Au}$ species [21, 26]; however, with lower $\mathrm{BE}$ than that of $\mathrm{Au}_{2} \mathrm{O}_{3}$ $(\mathrm{BE} 85.9 \mathrm{eV})$ [27, 28]. Under $\mathrm{O}_{3}$ the numbers of low coordinated $\mathrm{Au}$ atom increasing, this is evidenced by an 
increase and broadening in low BE peak at $83.5 \mathrm{eV}$. According to Weststrate et al. [22] the less neighbors the lower $\mathrm{BE}$, in other words an oxidation restructures $\mathrm{Au}$ surface and forms low-coordinated $\mathrm{Au}$ atoms (for example edges, kinks, etc.) on the surface. The surface sensitive $\mathrm{O}$ 1s spectrum [Fig. 3b(ii)] is broader in comparison with one measured in UHV. The $\mathrm{O}$ 1s spectrum in $\mathrm{O}_{3}$ atmosphere consists of at least two components: the high $\mathrm{BE}$ species are associated with carbon-oxygen species (BE $532.6 \mathrm{eV}$ ) while the low $\mathrm{BE}$ component corresponds to oxygen on $\mathrm{Au}$ $(\mathrm{BE} 530.1 \mathrm{eV})[21,29]$. A decrease in intensity of $\mathrm{C} 1 \mathrm{~s}$ spectrum [Fig. 1c(ii)] is due to scattering of photoelectron in gas phase.

As was shown in our previous work [30], all signs of gold oxide vanish when $\mathrm{O}_{3}$ is evacuated from the chamber. Even an $\mathrm{O}_{2}$-rich gas mixture $\left(\mathrm{CO} / \mathrm{O}_{2}=1: 75\right)$ does not prevent the decomposition of the oxide [Fig. 1(iii)]. In contrast to the changes found for extended Au surfaces exposed to ozone [30], the Au 4f spectral shape of Au NPs remains unchanged after $\mathrm{O}_{3}$ treatment [Fig. 1a(iii)]. The low $\mathrm{BE}$ components of the $\mathrm{Au} 4 \mathrm{f}$ spectra does not change much, only small intensity decrease, which can be due to sintering or/and carbon accumulation [Fig. 1c(iii)]. Consistently, the peak shape of the $\mathrm{O} 1 \mathrm{~s}$ spectrum returns to nearly the same shape as when measured in UHV, but with a slightly broader width due to the formation of new carbon-oxygen species. Note that only oxygen bonding to the carbon remains on the surface.

The quantitative analysis of surface composition is presented in Table 1. The dominant element on the surface

Table 1 Surface composition of Au/HOPG at different conditions

\begin{tabular}{lllll}
\hline & $\mathrm{Au}^{0}($ at.\%) & $\mathrm{Au}^{3+}($ at.\%) & $\mathrm{O}$ (at.\%) & $\mathrm{C}($ at.\%) \\
\hline $\mathrm{UHV}$ & 16.5 & - & 5.0 & 78.5 \\
$\mathrm{O}_{3}$ & 7.4 & 4.6 & 9.5 & 75.5 \\
$\mathrm{CO}+\mathrm{O}_{2}$ & 8.0 & - & 10.3 & 81.7 \\
\hline
\end{tabular}
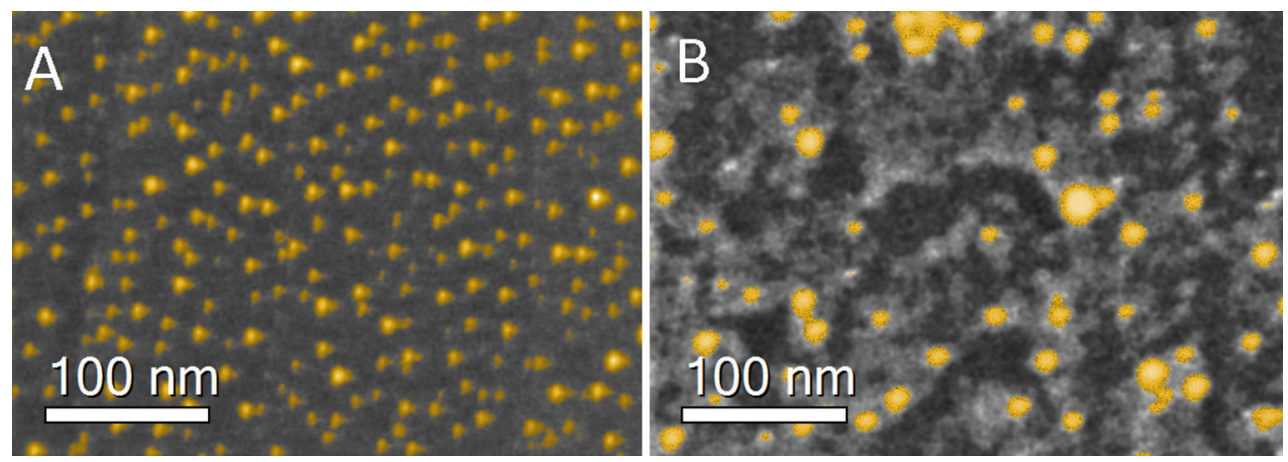

Fig. 2 SEM image of Au/HOPG a before and $\mathbf{b}$ after $\mathrm{O}_{3}$ treatment at $250{ }^{\circ} \mathrm{C}$ and $\mathrm{CO}$ oxidation. Images were colorized in order to highlight the differences between the two samples 

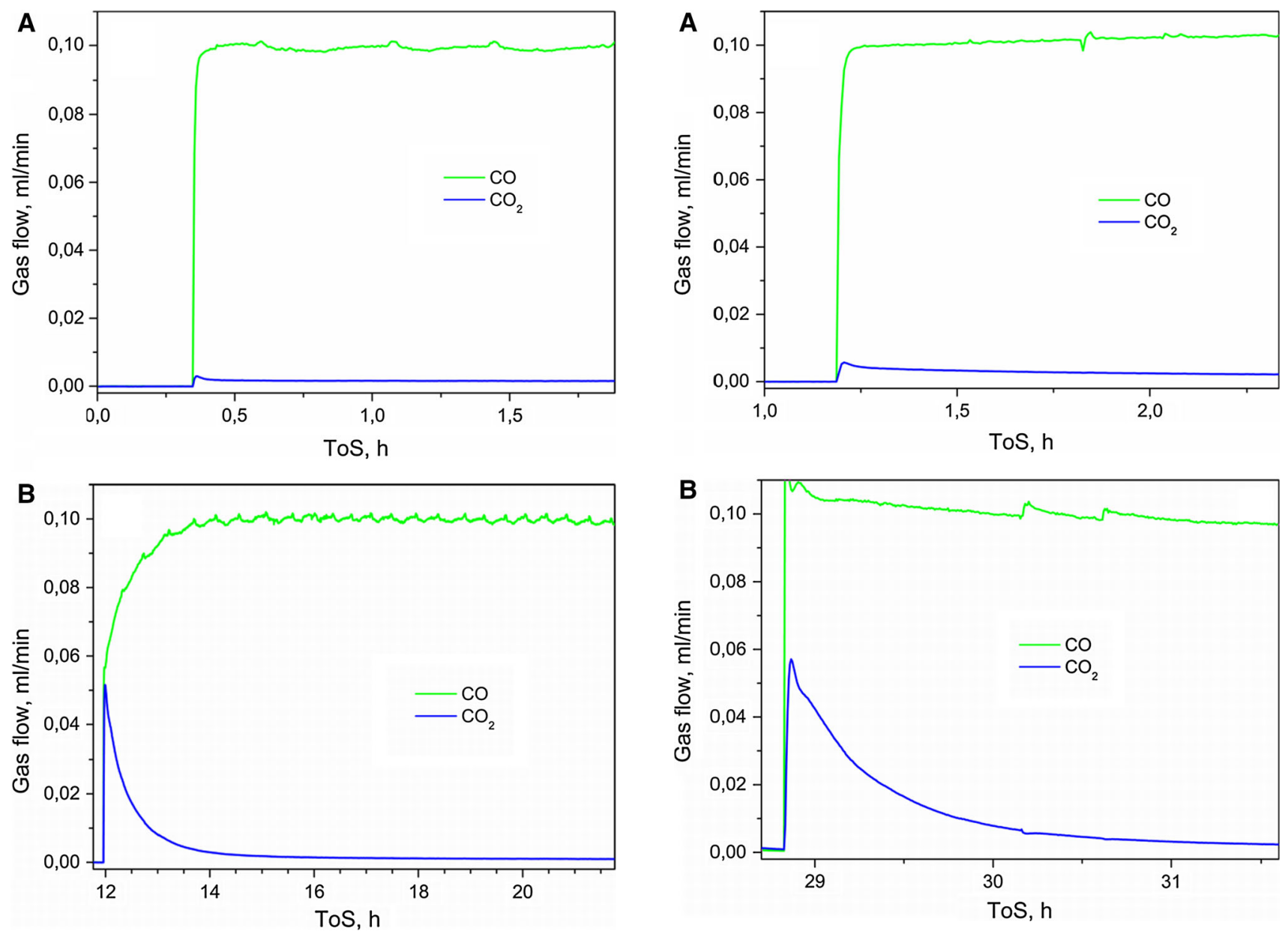

Fig. 3 QMS data of Au/HOPG a before and $\mathbf{b}$ after $\mathrm{O}_{3}$ treatment at $p=0.3$ mbar, $\mathrm{RT}$ and $\mathrm{CO}: \mathrm{O}_{2}=1: 75$ ratio

Fig. 4 QMS data of HOPG a before and $\mathbf{b}$ after $\mathrm{O}_{3}$ treatment at $p=0.3$ mbar, $\mathrm{RT}$ and $\mathrm{CO}: \mathrm{O}_{2}=1: 75$ ratio

the sample not pre-treated with $\mathrm{O}_{3}$, but a strong deactivation takes place, and after approximately $2 \mathrm{~h}$ the $\mathrm{CO}_{2}$ yield is negligible. Thus the aglomeration does not influence the activity of $\mathrm{Au} / \mathrm{HOPG}$, suggesting that other reasons apart of the structural changes are responsible of the activation of $\mathrm{Au}$. We assume that the increase of the $\mathrm{CO}_{2}$ yield after the $\mathrm{O}_{3}$ treatment is caused by the stoichiometric reaction between the remaining surface oxygen and CO.

\subsection{Au/N-CNTs and Au/O-CNTs}

Similar results were obtained for Au NPs on nitrogen- and oxygen-functionalized carbon nanotubes $(\mathrm{Au} / \mathrm{N}-\mathrm{CNTs}$ and $\mathrm{Au} / \mathrm{O}-\mathrm{CNTs})$. The Au particle size was $<5 \mathrm{~nm}$. The $\mathrm{Au}$ NPs on functionalized CNTs consisted of a few large (ca. $40 \mathrm{~nm}$ diameter) particles, sparsely distributed along the tubes (not shown), along with a majority of densely dispersed nanoclusters visible only by STEM (ESI, Fig. S1). Under the same conditions, the fresh samples were inactive for $\mathrm{CO}$ oxidation as $\mathrm{Au} / \mathrm{HOPG}$, in spite of the significant

increase of the catalyst surface area that resulted from the higher support area and Au size reduction. After $\mathrm{O}_{3}$ treatment, $\mathrm{Au} / \mathrm{N}-\mathrm{CNTs}$ and $\mathrm{Au} / \mathrm{O}-\mathrm{CNTs}$ show the same initial activity profile as discussed for Au/HOPG and, the same rate of deactivation $(\sim 2.5 \mathrm{~h})$ (not shown).

\subsection{HOPG}

In order to prove that stoichiometric reaction takes place, 'blank' measurements were done. A pristine HOPG crystal was placed in the sample holder and all treatment procedures were repeated. The QMS results are shown in the Fig. 4. Untreated HOPG does not catalyze the oxidation of $\mathrm{CO}$ as clearly shown in the Fig. 4a. However after interaction with $\mathrm{O}_{3}$, HOPG demonstrates an initial high $\mathrm{CO}$ conversation that strongly decreases with time. Since HOPG contains only carbon atoms, the origin of sample's activity can be attributed only to the stoichiometric reaction between chemisorbed oxygen on the HOPG surface and $\mathrm{CO}$ in the gas phase. 


\subsection{Au/Au Foil}

To further corroborate the idea that the reactivity is due to a stoichiometric reaction between $\mathrm{CO}$ and $\mathrm{O}$ functional groups on the carbon surface, we investigated $\mathrm{Au}$ nanoparticles supported on oxygen-free $\mathrm{Au}$ foil. The $\mathrm{Au}$ foil was chosen as a support because it is expected to be inactive in $\mathrm{CO}$ oxidation.

After preparation, the surface composition of the $\mathrm{Au} / \mathrm{Au}$ foil is very important. All fitting parameters are given in Tables $\mathrm{S} 1$ and $\mathrm{S} 2$ in the ESI. The corresponding Au $4 \mathrm{f}$ spectrum [Fig. 5a(i)] of Au/Au foil shows the metallic peak at a $\mathrm{BE}$ of $83.95 \mathrm{eV}$ with second component shifted to the low $\mathrm{BE}$ by $0.3 \mathrm{eV}$. This peak is assigned to the surface core-level shift $[32,33]$, which is ascribed mainly to the lower coordination of surface atoms compared to bulk atoms. The $\mathrm{O} 1 \mathrm{~s}$ spectrum [Fig. 5b(i)] displays one broad peak at $\mathrm{BE}$ of $532.5 \mathrm{eV}$, which is in the range observed for carbonates and oxygen-containing (hydro)carbons on gold [34]. The presence of carbonates and/or oxygen-containing (hydro)carbons on the surface is confirmed by the $\mathrm{C} 1 \mathrm{~s}$ spectrum [Fig. 5c(i)].

To clean the $\mathrm{Au}$ surface from the surface carbon impurities, an $\mathrm{O}_{3}$ treatment at $150{ }^{\circ} \mathrm{C}$ was performed. When we apply the combination of high temperature $\left(150{ }^{\circ} \mathrm{C}\right)$ and very reactive treatment $\left(\mathrm{O}_{3}\right)$ the carbon is burned of very rapidly, as is clearly visible in the
Fig. 5c(ii). The influence of the $\mathrm{O}_{3}$ to the sample is not limited only to the burning of the carbon, but also the oxidation of the Au surface takes place. The corresponding $\mathrm{Au} 4 \mathrm{f}$ spectrum [Fig. 5a(ii)] reveals the formation of $\mathrm{Au}$ oxide, the broad peak at $\mathrm{BE}$ of $85.25 \mathrm{eV}$ appears under $\mathrm{O}_{3}$ conditions, which is assigned to an ionic $\mathrm{Au}$ species [21, 26]. Simultaneously, a new feature in comparison with the untreated sample appears in low BE region $(\mathrm{BE}=83.3 \mathrm{eV})$, which is assigned to the surface restructuring during oxidation $[30,35]$. The $\mathrm{O}$ 1s spectrum Fig. 5b(ii)] has also undergone changes: the broad peak at $532.5 \mathrm{eV}$ vanishes due to carbon removal and a double peak in the lower BE region is formed. The component with $\mathrm{BE}$ of $529.4 \mathrm{eV}$ can be assigned to a surface oxide or chemisorbed oxygen on $\mathrm{Au}[29,36,37]$; the other component $(\mathrm{BE}=531.1 \mathrm{eV})$ has to be attributed to $\mathrm{O}$ in water and/or hydroxyl groups [21, 29], but also the oxidation of contaminants in concentrations below the detection limits of XPS cannot be excluded [29].

After $\mathrm{O}_{3}$ cleaning the sample was cooled down to RT and $\mathrm{O}_{3}$ was substituted by $\mathrm{O}_{2}$. The cooling leads to immediate carbon accumulation as shown in the $\mathrm{C} 1 \mathrm{~s}$ spectrum [Fig. 5c(iii)]. The high $\mathrm{BE}$ tail of the $\mathrm{C} 1 \mathrm{~s}$ spectrum indicates the formation of $\mathrm{C}-\mathrm{O}$ and $\mathrm{C}=\mathrm{O}$ bonds on the surface during cooling in $\mathrm{O}_{3}$ and further treatment in $\mathrm{O}_{2}$. The $\mathrm{O} 1 \mathrm{~s}$ spectrum in $\mathrm{O}_{2}$ [Fig. 5b(iii)] confirms the formation of oxygen-containing (hydro)carbons on the $\mathrm{Au}$

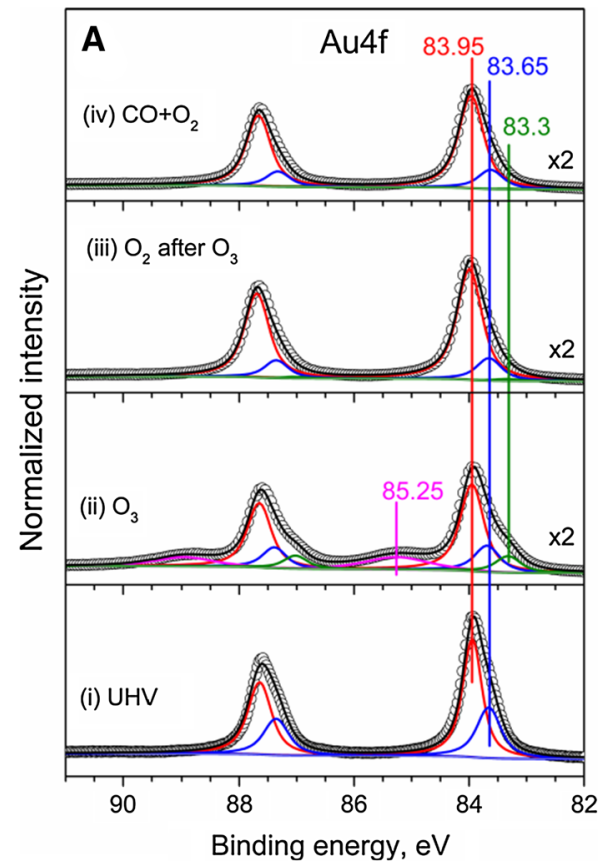

Fig. 5 NAP a Au 4f, b O 1s and c C 1s XP spectra of Au/Au foil (i) in UHV at RT, (ii) under $\mathrm{O}_{3}$ at $p=0.3 \mathrm{mbar}, \mathrm{T}=150{ }^{\circ} \mathrm{C}$, (iii) under $\mathrm{O}_{2}$ after $\mathrm{O}_{3}$ treatment at $p=0.3 \mathrm{mbar}$, RT and (iv) under $\mathrm{CO}$ and $\mathrm{O}_{2}$ atmosphere $\left(\mathrm{CO}: \mathrm{O}_{2}=1: 75\right)$ at $p=0.3$ mbar, $\mathrm{RT}$.
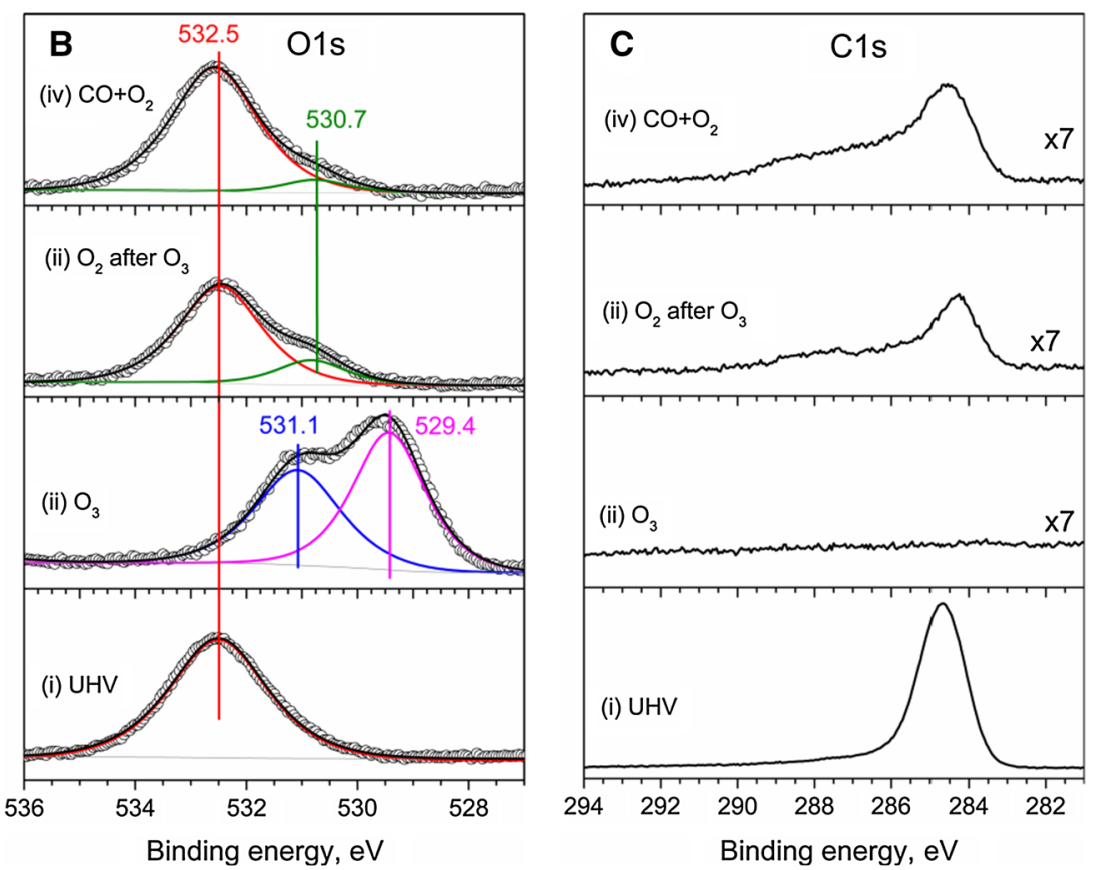

Photoelectrons with $150 \mathrm{eV}$ kinetic energy were used to collect surface sensitive $\mathrm{Au} 4 \mathrm{f}, \mathrm{O} 1 \mathrm{~s}$ and $\mathrm{C}$ 1s spectra in UHV, and photons with $720 \mathrm{eV}$ energy were used to collect $\mathrm{Au} 4 \mathrm{f}, \mathrm{O}$ 1s and $\mathrm{C}$ 1s spectra in $\mathrm{O}_{3}, \mathrm{O}_{2}$ and $\mathrm{CO}+\mathrm{O}_{2}$ atmospheres 
surface, corresponding peak at $532.5 \mathrm{eV}$ is well pronounced. In addition a small peak at $530.7 \mathrm{eV}$ arises, and can be assigned to residual oxidized impurities in concentrations below XPS detection limit or to (hydro)carbons adsorbed on the low-coordinated atoms (defects) on the surface. There is no peak $(\mathrm{BE}<530 \mathrm{eV})$ related to the $\mathrm{Au}$ oxide(s). Also no signs of Au oxide(s) (BE $85.25 \mathrm{eV}$ ) are in the Au $4 \mathrm{f}$ spectrum [Fig. 5a(iii)], but deconvolution of the spectrum shows that the peak assigned to the surface reconstruction $\left(\mathrm{BE} 83.3 \mathrm{eV}\right.$ ) remains. Therefore, $\mathrm{O}_{3}$ evacuation leads to decomposition of oxide(s) and carbon accumulation.

Following $\mathrm{O}_{3}$ treatment, we introduced a reaction mixture $\left(\mathrm{CO} / \mathrm{O}_{2}=1: 75\right)$ into the chamber. The spectra do not change substantially. Further carbon accumulation occurs, as is seen by the increase in intensity of the $\mathrm{C} 1 \mathrm{~s}$ peak [Fig. 5c(iv)]. The shapes of the O 1s [Fig. 5b(iv)] and Au 4f [Fig. 5a(iv)] spectra are similar in general to the ones measured in $\mathrm{O}_{2}$ atmosphere; only the intensity of the peak $(\mathrm{BE}=530.7 \mathrm{eV})$ corresponding to residual residual oxidized impurities with concentrations below XPS detection limit or to (hydro)carbons adsorbed on the low-coordinated atoms (defects) decreases.

Quantification of the surface composition of $\mathrm{Au} / \mathrm{Au}$ foil is presented in Table 2. The untreated sample is mostly covered by carbon (69.0 at.\%). Nevertheless initial considerable carbon coverage $\mathrm{O}_{3}$ treatment cleans surface from carbon totally. Contemporaneously to carbon burning $\mathrm{Au}$ oxidation takes place during $\mathrm{O}_{3}$ treatment, oxygen

Table 2 Surface composition of $\mathrm{Au} / \mathrm{Au}$ foil at different conditions

\begin{tabular}{lllll}
\hline & $\mathrm{Au}^{0}($ at.\%) & $\mathrm{Au}^{3+}($ at.\%) & $\mathrm{O}($ at.\%) & $\mathrm{C}($ at.\%) \\
\hline $\mathrm{UHV}$ & 24.8 & - & 6.2 & 69.0 \\
$\mathrm{O}_{3}$ & 47.7 & 8.9 & 41.8 & $<1.5$ \\
$\mathrm{O}_{2}$ & 37.3 & - & 23.4 & 39.3 \\
$\mathrm{CO}+\mathrm{O}_{2}$ & 8 & - & 10.3 & 81.7 \\
\hline
\end{tabular}

concentration on the surface in $\mathrm{O}_{3}$ atmosphere exceeds stoichiometric ratio of $\mathrm{Au}_{2} \mathrm{O}_{3}$, which indicates the presence of an additional adsorbed oxygen overlayer. Changing chemical potential from $\mathrm{O}_{3}$ to $\mathrm{O}_{2}$ leads the decomposition of the surface oxide and fast carbon accumulation
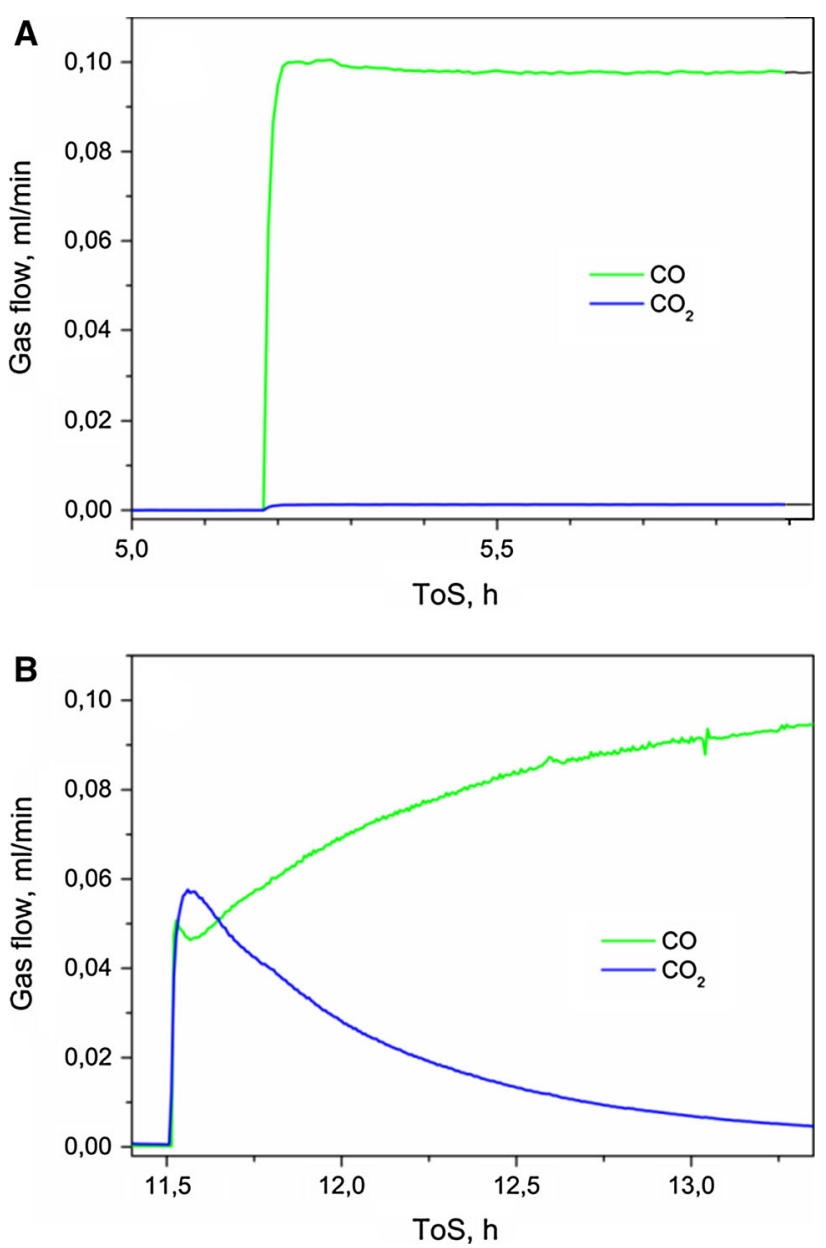

Fig. 7 QMS data of $\mathrm{Au} / \mathrm{Au}$ foil $\mathbf{a}$ before and $\mathbf{b}$ after $\mathrm{O}_{3}$ treatment at $p=0.3$ mbar, $\mathrm{RT}$ and $\mathrm{CO}: \mathrm{O}_{2}=1: 2$ ratio
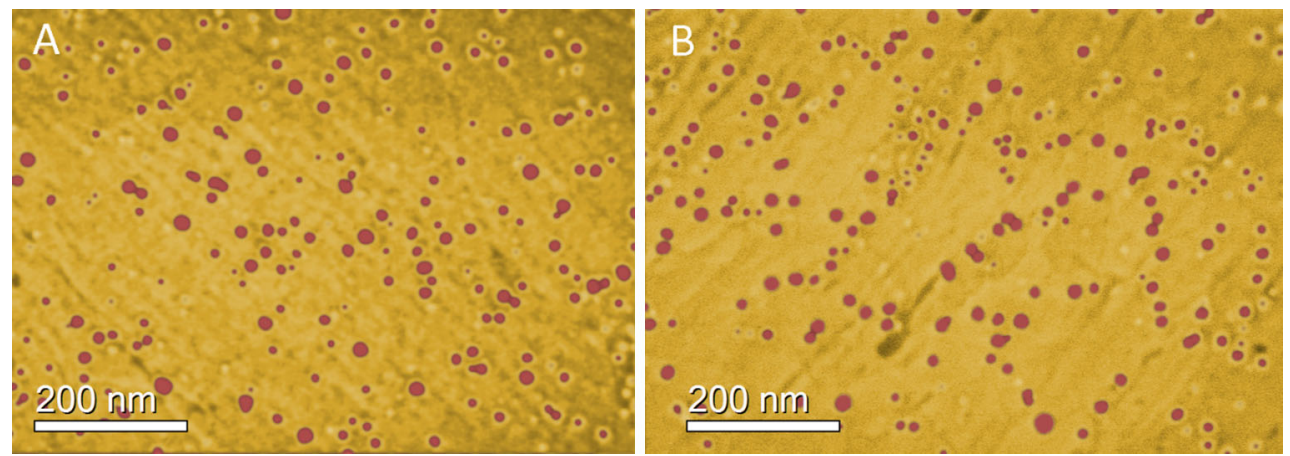

Fig. 6 SEM images of $\mathrm{Au} / \mathrm{Au}$ foil $\mathbf{a}$ before and $\mathbf{b}$ after $\mathrm{O}_{3}$ treatment. Images were colorized in order to highlight the differences between the two samples 

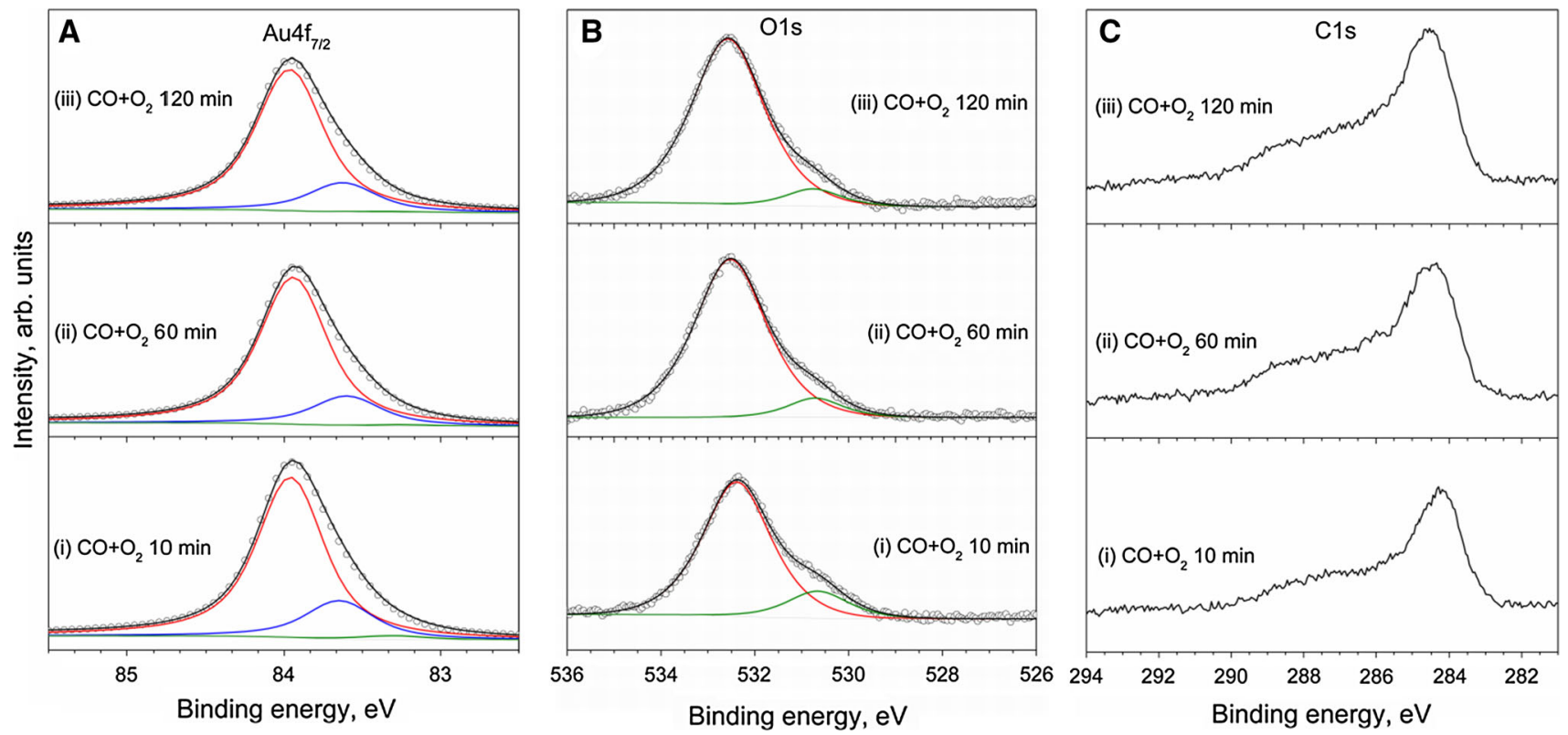

Fig. 8 NAP a Au 4f, $\mathbf{b} \mathrm{O} 1 \mathrm{~s}$ and $\mathbf{c} \mathrm{C} 1 \mathrm{~s}$ XP spectra of $\mathrm{Au} / \mathrm{Au}$ foil under $\mathrm{CO}$ reaction after $\mathrm{O}_{3}$ treatment at $p=0.3 \mathrm{mbar}$, RT (i) after 10 min, (ii) $60 \mathrm{~min}$ and (iii) $120 \mathrm{~min}$. Photons with $720 \mathrm{eV}$ energy were used to collect $\mathrm{Au} 4 \mathrm{f}, \mathrm{O}$ 1s and $\mathrm{C}$ 1s spectra

(39.3 at.\%); carbon comes from the wall of the chamber. Following $\mathrm{CO}$ oxidation only facilitates further increasing carbon concentration on the surface of $\mathrm{Au} / \mathrm{Au}$ foil.

Microscopy does not reveal big differences between fresh and oxidized samples. SEM images of untreated Au/ Au foils show a particle size of ca. $10 \mathrm{~nm}$ (Fig. 6a). In turn, the $\mathrm{Au}$ particle size distribution on $\mathrm{O}_{3}$-treated samples shows some sintering effects and a slightly rougher surface (Fig. 6b).

A fresh electrochemically prepared sample $\mathrm{Au} / \mathrm{Au}$ foil was tested under reaction conditions (Fig. 7a). The presence of the sample in the set-up does not influence the $\mathrm{CO}$ conversion. The $\mathrm{CO}_{2}$ yield is negligible for the overall measurements. There are two possible explanation: (1) the adsorption of (hydro)carbons (See XPS part), which cover the surface, may prevent access of the gas mixture to the catalyst surface; or (2) $\mathrm{Au} / \mathrm{Au}$ foil is an inactive catalyst. Our experiments with Au NPs $(\sim 15 \mathrm{~nm})$ supported on transition metal oxides $\left(\mathrm{Au} / \mathrm{TiO}_{2}\right.$ and $\left.\mathrm{Au} / \mathrm{Fe}_{2} \mathrm{O}_{3}\right)$ in $\mathrm{CO}$ oxidation conducted under similar conditions show catalytic activity of the samples despite a big particle size and the presence of carbon on the surface up to 60 at.\% [38], therefore surface (hydro)carbons are not relevant for inertness of Au NPs on oxygen-free supports.

However, the oxidized Au sample looks more promising, but is not stable for long times (Fig. 7b). CO consumption and deactivation time $(2 \mathrm{~h})$ are similar to those observed on Au/HOPG. The corresponding Au 4f, O 1s and $\mathrm{C}$ 1s spectra are shown in Fig. 8. In the Au $4 \mathrm{f}$ spectrum (Fig. 8a) the peak assigned to surface reconstruction (BE
$83.3 \mathrm{eV}$ ) is present in a small amount. The overall intensity of the spectra decreases with time. The two components of the $\mathrm{O}$ 1s spectra (Fig. 8b) show opposite behavior: the oxygen-containing (hydro)carbons $(\mathrm{BE}=532.5 \mathrm{eV})$ peak increases, while the intensity of the peak $(\mathrm{BE}=530.7 \mathrm{eV})$ corresponding to residual residual oxidized contaminants with concentrations below XPS detection limit or to (hydro)carbons adsorbed on the low-coordinated atoms (defects) decreases during the reaction. The explanation of such behavior can be that the reaction occurs between oxidized (hydro)carbons $\left(\mathrm{O}_{3}\right.$ functionalized carbon all over the chamber) and $\mathrm{CO}$ molecules. When the oxygen supply is depleted the reaction stops, and carbon accumulation takes place, which is evident from increasing of $\mathrm{C} 1 \mathrm{~s}$ peak (Fig. 8c). Thus, oxidized Au/Au foil itself does not catalyze $\mathrm{CO}$ oxidation at low temperature.

\section{Conclusions}

The results presented here indicate that Au NPs supported on oxygen-free substrates are not active catalysts in $\mathrm{CO}$ oxidation, unless an external source of oxygen is provided. This behavior is found to be independent of the method of preparation and the nature of the support. $\mathrm{O}_{3}$ treatment allows cleaning of the surface, but at the same time to functionalize the carbon all over the chamber including the support. Oxygen-functionalized (hydro)carbon may still be present if their removal by $\mathrm{O}_{3}$ treatment was not completed, and can react with $\mathrm{CO}$. The stoichiometric reaction 
ends rather soon after reaction initiation, and $\mathrm{O}_{2}$ alone cannot re-functionalize the (hydro)carbons.

Under a constant chemical potential of $\mathrm{O}_{3}$, an $\mathrm{Au}$ oxide is formed, but evacuation or substitution of $\mathrm{O}_{3}$ by $\mathrm{O}_{2}$ results in the disappearance of the surface oxide. Therefore, participation of $\mathrm{Au}$ oxide in $\mathrm{CO}$ oxidation can be excluded. Remaining low-coordinated atoms do not have sufficient catalytic properties, and $\mathrm{CO}$ oxidation does not occur on the Au NPs even after oxidation. Our results clearly show that the size reduction andlor the oxidation of $\mathrm{Au}$ is not an effective strategy to activate Au.

Acknowledgments We thank HZB for the allocation of synchrotron radiation beamtime, Gisela Weinberg (Fritz-Haber-Institute der MaxPlanck, Berlin) for the SEM characterization, Manfred Schuster (Fritz-Haber-Institute der Max-Planck, Berlin) and Xing Huang (Fritz-Haber-Institute der Max-Planck, Berlin) for the TEM images and Klaus Friedel (Fritz-Haber-Institute der Max-Planck, Berlin) for sample preparation. AVB, IPP and VIB thank the Russian Science Foundation (Grant 14-23-00146) for financial support.

Open Access This article is distributed under the terms of the Creative Commons Attribution 4.0 International License (http://crea tivecommons.org/licenses/by/4.0/), which permits unrestricted use, distribution, and reproduction in any medium, provided you give appropriate credit to the original author(s) and the source, provide a link to the Creative Commons license, and indicate if changes were made.

\section{References}

1. Haruta M, Yamada N, Kobayashi T, Iijima S (1989) J Catal 115:301-309

2. Haruta M, Tsubota S, Kobayashi T, Kageyama H, Genet MJ, Delmon B (1993) J Catal 144:175-192

3. Haruta M, Daté M (2001) Appl Catal A Gen 222:427-437

4. Hashmi ASK, Hutchings GJ (2006) Angew Chem Int Ed 45:7896-7936

5. Laguna OH, Romero-Sarria F, Centeno MA, Odriozola JA (2010) J Catal 276:360-370

6. Ryabenkova Y, He Q, Miedziak PJ, Dummer NF, Taylor SH, Carley AF, Morgan DJ, Dimitratos N, Willock DJ, Bethell D, Knight DW, Chadwick D, Kiely CJ, Hutchings GJ (2013) Catal Today 203:139-145

7. Hayashi T, Tanaka K, Haruta M (1998) J Catal 178:566-575

8. Tripathi AK, Kamble VS, Gupta NM (1999) J Catal 187:332-342

9. Bär T, Visart de Bocarmé T, Nieuwenhuys BE, Kruse N (2001) Catal Letters 74:127-131

10. Guillemot D, Borovkov VYu, Kazansky VB, Polisset-Thfoin M, Fraissard J (1997) J Chem Soc Faraday Trans 93:3587-3591
11. Boccuzzi F, Chiorino A, Manzoli M, Lu P, Akita T, Ichikawa S, Haruta M (2001) J Catal 202:256-267

12. Chen MS, Goodman DW (2004) Science 306:252-255

13. Yoon B, Häkkinen H, Landman U, Wörz AS, Antonietti J-M, Abbet S, Judai K, Heiz U (2005) Science 307:403-407

14. Minicò S, Scirè S, Crisafulli C, Visco AM, Galvagno S (1997) Catal Letters 47:273-276

15. Demidov DV, Prosvirin IP, Sorokin AM, Rocha T, Knop-Gericke A, Bukhtiyarov VI (2011) Catal Sci Technol 1:1432-1439

16. Knop-Gericke A, Kleimenov E, Hävecker M, Blume R, Teschner D, Zafeiratos S, Schlögl R, Bukhtiyarov VI, Kaichev VV, Prosvirin IP, Nizovskii AI, Bluhm H, Barinov A, Dudin P, Kiskinova M (2009) Adv Catal 52:213-272

17. Bluhm H, Hävecker M, Knop-Gericke A, Kleimenov E, Schlögl R, Teschner D, Bukhtiyarov VI, Ogletree DF, Salmeron M (2004) J Phys Chem B 108:14340-14347

18. Yeh JJ, Lindau I (1985) At Data Nucl Data Tables 32:1-155

19. Canning NDS, Outka D, Madix RJ (1984) Surf Sci 141:240-254

20. King DE (1995) J Vac Sci Technol A 13:1247-1253

21. Koslowski B, Boyen H-G, Wilderotter C, Kästle G, Ziemann P, Wahrenberg R, Oelhafen P (2001) Surf Sci 475:1-10

22. Weststrate CJ, Lundgren E, Andersen JN, Rienks EDL, Gluhoi AC, Bakker JW, Groot IMN, Nieuwenhuys BE (2009) Surf Sci 603:2152-2157

23. Desimoni E, Casella GI, Morone A, Salvi AM (1990) Surf Interface Anal 15:627-634

24. Kundu S, Wang Y, Xia W, Muhler M (2008) J Phys Chem C 112:16869-16878

25. Witek G, Noeske M, Mestl G, Shaikhutdinov S, Behm RJ (1996) Catal Lett 37:35-39

26. Tsai H, Hu E, Perng K, Chen M, Wu J-C, Chang Y-S (2003) Surf Sci 537:L447-L450

27. Juodkazis K, Juodkazyte J, Jasulaitiene V, Lukinskas A, Sebeka B (2000) Electrochem Commun 2:503-507

28. Dickinson T, Povey AF, Sherwood PMA (1975) J Chem Soc Faraday Trans 71:298-311

29. Krozer A, Rodahl M (1997) J Vac Sci Technol, A 15:1704-1709

30. Klyushin AYu, Rocha TCR, Hävecker M, Knop-Gericke A, Schlögl R (2014) Phys Chem Chem Phys 16:7881-7886

31. Tandon D, Hippo EJ, Marsh H, Sebok E (1997) Carbon 35:35-44

32. Citrin PH, Wertheim GK, Baer Y (1978) Phys Rev Lett 41:1425-1428

33. Heimann P, van der Veen JF, Eastman DE (1981) Solid State Commun 38:595-598

34. Schaefer A, Ragazzon D, Wittstock A, Walle LE, Borg A, Bäumer M, Sandell A (2012) J Phys Chem C 116:4564-4571

35. Weststrate CJ, Lundgren E, Andersen JN, Rienks EDL, Gluhoi AC, Bakker JW, Groot IMN, Nieuwenhuys BE (2009) Surf Sci 603:2152-2157

36. Saliba N, Parker DH, Koel BE (1998) Surf Sci 410:270-282

37. Min BK, Alemozafar AR, Biener MM, Biener J, Friend CM (2005) Top Catal 36:77-90

38. Klyushin AYu, Greiner MT, Huang X, Lunkenbein T, Li X, Timpe O, Friedrich M, Hävecker M, Knop-Gericke A, Schlögl R (under review) ACS Catalysis 